\title{
Implementasi Treatment and Education of Autistic and Realted Communication- handicapped Children (TEACCH) pada Kemampuan Bina Diri Anak Down Syndrome
}

\author{
Ismanura Firdaus, Rizqi Fajar Pradipta \\ Universitas Negeri Malang \\ E-mail: ismanurafirdaus@gmail.com
}

\begin{abstract}
Abstrak: Anak down syndrome memiliki perkembangan kognitif yang menunjukkan adanya hambatan intelektual. Salah satu karakteristiknya yaitu rendahnya kemampuan bina diri. Tujuan penelitian ini adalah untuk mendeskripsikan pengaruh metode TEACCH terhadap kemampuan bina diri memakai baju siswa down syndrome. Rancangan penelitian ini menggunakan metode eksperimen jenis SSR dengan desain A-B-A'. Kesimpulan dari penelitian ini bahwa intervensi menggunakan metode TEACCH dapat membentuk kemampuan bina diri memakai baju siswa down syndrome.
\end{abstract}

Kata kunci: Metode TEACCH; Kemampuan bina diri memakai baju; Down syndrome

\begin{abstract}
Children with Down syndrome have coginitive development that shows intellectual delay. One of the characteristics is the low ability of self-development. The aim of this research are to describe the effect of the TEACCH method on the ability to develop themselves using down syndrome students' clothes. The research was arranged based on the design of the experimental method with a Single Subject Research (SSR) with the A-B-A design. The conclusion of this research is that the intervention using the TEACCH method can establish the ability to wear clothes of Down syndrome students 'clothing.

Keywords: TEACCH Method; Self Skill Ability to Wear Clothes; Syndrome Down
\end{abstract}

Keterampilan paling dasar dalam dunia kebutuhan dunia kebutuhan khusus disebut dengan Activity Daily Living(ADL). Setiap orang membutuhkan keterampilan tertentu untuk sekedar menjalani hari. Keterampilan yang berkaitan dengan ADL anak berkebutuhan khusus dapat dijabarkan melalui istilah bina diri. Widati (2013) menjelaskan bahwa spectrum bina diri bagi ABK mencakup lingkup pembelajaran yang luas yaitu tiap anak berkebutuhan khusus memerlukan ADL yang berbeda. Perbedaan itu berkaitan dengan hambatan tiap anak yang membutuhkan variasi cara, alat, ataupun metode yang dapat digunakan tiap anak berkebutuhan khusus dalam berlatih. Shenai (2014) menjelaskan bahwa keterampilan bina diri adalah komponen integral dari perkembangan global anak. Salah satu keterampilan dalam bina diri yaitu memakai baju. Nigam \& Tuteja (2017) menjelaskan bahwa berpakaian memberikan anak kesempatan untuk mempraktikkan kemandirian dan batas kemampuan mereka dalam ruang lingkup ADL. Pakaian dapat dianggap sebagai salah satu masalah lingkungan kecil bagi anak-anak disabilitas dengan segala keterbatasannya.

Anak down syndrome merupakan salah satu penyandang disabilitas yang memiliki hambatan perkembangan fisik dan mental yang ditandai dengan kelainan kromosom. Adanya abnormalitas perkembangan kromosom 21 yang tidak berhasil memisahkan diri selama pembelahan sehingga terjadi individu dengan 47 kromosom (Meinapuri, 2013). Down syndrome merupakan gangguan yang juga tergolong sebagai kondisi kelainan yang muncul sejak lahir seperti retardasi mental, perbedaan fisik tertentu seperti bentuk wajah yang sedikit datar dan meningkatkannya resiko pada kondisi medis termasuk gangguan hati, hambatan yang berhubungan dengan usus dan kerusakan penglihatan maupun pendengaran (Amherstia, 2016). Anak down syndrome memiliki IQ di bawah rata-rata dan kesulitan dalam menerima pembelajaran karena mereka membutuhkan waktu yang lama, maka keterampilan ADL yang diajarkan memerlukan metode pembelajaran bina diri yang bisa disesuaikan dengan kondisinya. Disusun sedemikian rupa sesuai dengan kebutuhan, karakteristik, dan hambatan anak serta bermanfaat bagi anak di kemudian hari.

Menurut DSAWM (2010) menjelaskan fakta karakteristik tentang down syndrome, sebagai berikut: a) down syndrome adalah kelainan kromosom paling umum pada manusia, b) down syndrome terjadi pada setiap 600- 800 angka kelahiran hidup dan tidak terkait dengan ras, kebangsaan, agama, atau status sosial ekonomi, c) meski usia ibu bisa menjadi salah satu faktor penyebab, $80 \%$ anak down syndrome dilahirkan oleh ibu di bawah usia 35 tahun, dengan usia rata-rata 26 tahun, d) down syndrome terjadi pada pria atau wanita secara merata, e) bukan karena adanya hal yang dilakukan ataupun tidak dilakukan seorang ibu yang menjadikan penyebab down syndrome.

Gunarhadi (2005) menyatakan bahwa anakanak dengan down syndrome ringan atau anak-anak yang mampu didik adalah mereka yang kemungkinan menerima pendidikan dalam kemandirian, menulis, dan berhitung pada tingkat tertentu di sekolah khusus. Down syndrome juga memengaruhi kemampuan 
seorang anak untuk berpikir, bernalar, memahami, dan bersosialisasi. Anak-anak dengan down syndrome sering membutuhkan waktu lebih lama untuk mencapai tujua-tujuan penting. Beberapa juga memiliki masalah dengan perilaku, mereka mungkin tidak memperhatikan dengan baik, atau mereka dapat menjadi obsesif tentang beberapa hal. Hal itu karena lebih sulit bagi mereka mengendalikan impuls mereka, berhubungan dengan orang lain, dan mengelola perasaan mereka ketika merasa frustasi.

Berdasarkan hasil pengamatan ditemukan bahwa terdapat siswa down syndrome yang kesulitan dalam kegiatan memakai baju secara mandiri. Salah satu kemampuan yang dapat diajarkan pada anak down syndrome adalah kemampuan bina diri melalui berbagai program pembelajaran yang menyenangkan dan mudah dipahami oleh siswa dengan penggunaan metode yang tepat. Oleh karenanya penggunaan berbagai metode mengajar yang tepat akan membawa dampak positif yang sesuai dalam meningkatkan keterampilan bina diri siswa down syndrome. Metode pengajaran yang tepat adalah metode yang mampu memberi pengaruh terhadap pencapaian siswa dalam beraktivitas kesehariannya.

Metode TEACCH (Treatment and Education of Autistic and Realted Communication-handicapped Children) bertujuan untuk mempromosikan pembelajaran dan pengembangan pada anak-anak berkebutuhan khusus. Gagasan kuncinya adalah mengajar anak-anak dengan cara yang memanfaatkan kekuatan dan mengatasi kelemahan anak berkebutuhan khusus. Bolagh, dkk (2013) menjelaskan bahwa metode TEACCH menggunakan pengajaran terstruktur untuk melatih anak-anak di bidang keterampilan sosial, keterampilan hidup, keterampilan bidang tertentu dan keterampilan komunikasi.

Pada dasarnya pengajaran berstruktur TEACCH ditujukan pada anak autis namun perlu diteliti juga apakah metode tersebut dapat diterapkan pada anak dengan down syndrome. Menurut Handojo (2009) mengemukakan salah satu pendekatan berstruktur yaitu metode ABA yang memecah keterampilan menjadi hal-hal kecil yang dapat dilakukan dan kemudian membangun keterampilan tersebut sehingga anak akan belajar bagaimana belajar di lingkungannya. Metode ABA merupakan metode yang tegas tanpa kekerasan baik untuk diterapkan pada anak-anak dengan gangguan perilaku lainnya selain autis. Sebagian kecil anak-anak dengan down syndrome juga didiagnosis dengan kondisi perkembangan yang disebut gangguan spektrum autis, yang mempengaruhi komunikasi dan interaksi sosial (GHR, 2019). Maka sama dengan metode TEACCH yang juga menggunakan pendekatan berstruktur dapat digunakan untuk anak dengan gangguan perilaku lainnya yaitu down syndrome. Metode TEACCH menumbuhkan kelebihan dan minat anak, dan mengembangkan struktur yang tepat yang mempromosikan keterampilan kerja mandiri anak juga mengembangkan kemampuan komunikasi dan sosial anak. Dijabarkan bahwa tujuan dari pengajaran berstruktur ini adalah untuk meningkatkan kemandirian anak, meningkatkan keterampilan dan mencegah masalah perilaku.

TEACCH berpusat pada 4 prinsip dasar. Mesibov \& Shea (2009) mengemukakan bahwa prinsip-prinsip metode TEACCH antara lain: a) penataan lingkungan, b) informasi visual, c) ketertarikan khusus sebagai penguat, d) komunikasi bermakna. Menurut Mesibov \& Shea (2009), penataan lingkungan yang didalamnya meliputi: (1) Struktur fisik mengacu pada tata letak aktual atau lingkungan siswa, seperti ruang kelas maupun rumah. Tujuan dari struktur fisik adalah pengaturan lingkungan utama sebagai pemisahan antara tempat yang digunakan untuk belajar maupun beristirahat, (2) Jadwal adalah bagian dari struktur pembelajaran yang dibutuhkan siswa. Tujuan dari penjadwalan adalah guru memiliki kerangka kerja agar dapat secara efektif mengajar siswa. (3) Sistem kerja yang berkenaan dengan materi dari tugas yang diberikan untuk memberi tahu pada anak apa yang diharapkan darinya selama suatu kegiatan, berapa banyak yang seharusnya dicapai, dan apa yang terjadi setelah kegiatan selesai. Tujuannya adalah untuk mengajari siswa untuk bekerja secara mandiri.

Informasi visual dapat membantu menyediakan struktur rutinitas, mendorong kemandirian, meningkatkan pemahaman, dan memberikan kesempatan untuk berinteraksi dengan orang lain.

Ketertarikan khusus sebagai penguat merupakan objek atau aktivitas yang disukai dan diminati siswa, yang dapat disediakan setelah pencapaian sebuah perilaku terlaksana, untuk meningkatkan frekuensi perilaku itu di masa depan. Komunikasi bermakna menggunakan bahasa yang bermakna pada pengajaran berstruktur yang berarti tidak setara dengan hanya belajar mengucapkan kata-kata selama latihan. Pengajaran terstruktur menganggap bahwa pemahaman reseptif adalah dasar untuk penggunaan komunikasi yang ekspresif.

\section{METODE}

Metode yang diterapkan adalah metode eksperimen. Berdasarkan permasalahan yang diteliti, peneliti menggunakan jenis penelitian eksperimen dalam bentuk Single Subject Research (SSR). Metode penelitian dengan subyek tunggal ini bertujuan untuk memperoleh data yang diperlukan dengan mengetahui ada tidaknya pengaruh variabel bebas yang digunakan sebagai intervensi terhadap variabel terikat. Penelitian ini akan melihat ada atau tidaknya pengaruh metode TEACCH untuk membentuk perilaku bina diri memakai baju pada siswa down syndrome. Desain penelitian yang peneliti terapkan dalam penelitian ini adalah desain A-B-A'. 


\section{Grafik 1 Struktur Dasar A-B-A'}

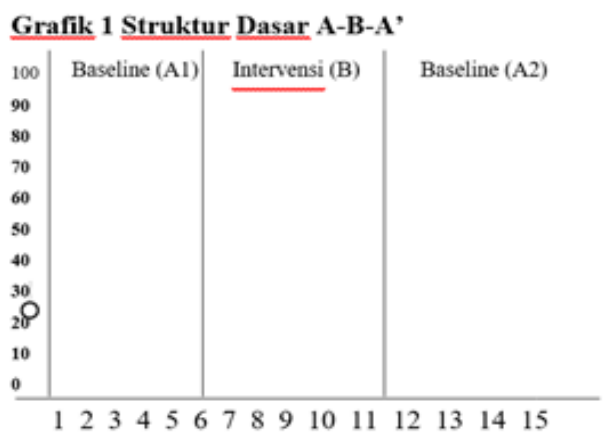

Tabel 1 Data Akumulasi Hasil Pengukuran Kemampuan Memakai Baju

\begin{tabular}{lll}
\hline Sesi & Kondisi & Nilai (\%) \\
\hline 1 & Baseline-1 (A1) & 47 \\
2 & & 56 \\
3 & & 58 \\
4 & & 61 \\
5 & & 61 \\
6 & Intervensi & 61 \\
1 & & 81 \\
2 & & 86 \\
3 & & 92 \\
4 & & 89 \\
5 & & 89 \\
6 & Baseline-2 (A2) & 78 \\
1 & & 81 \\
2 & & 86 \\
3 & & \\
\hline
\end{tabular}

\section{Grafik 2 Data Akumulasi Hasil Pengukuran Kemampuan Memakai Baju}

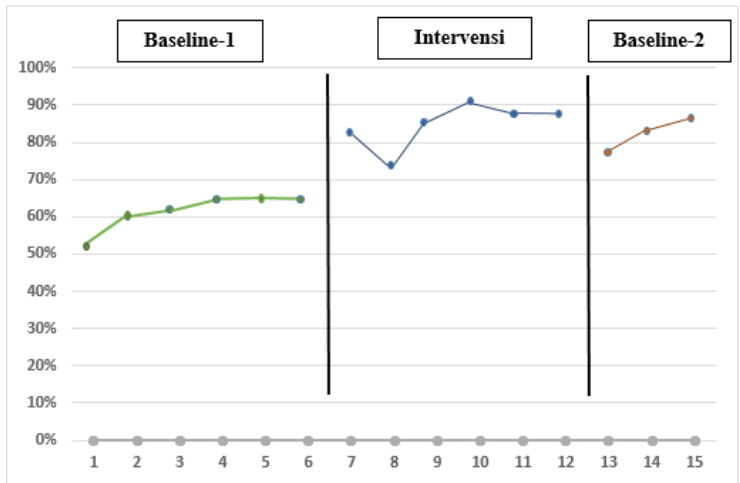

Baseline-1 (A1) yaitu lambang dari data garis dasar (baseline dasar). Fase baseline-1 (A1) merupakan kondisi saat pengukuran target behaviour yang dilakukan pada kondisi awal sebelum diberikan intervensi. Kemampuan siswa diukur tanpa adanya intervensi apapun pada fase ini. Pengukuran yang diterapkan untuk fase ini sebanyak tiga sesi dengan durasi waktu yang disesuaikan dengan kebutuhan.
Intervensi (B) adalah gambaran kondisi mengenai kemampuan siswa selama diberikan intervensi secara berulang-ulang melalui pengamatan hasil selama penerapan intervensi. Fase intervensi (B) merupakan kondisi yang menunjukkan suatu intervensi telah diberikan dan target behavior diukur berdasarkan kondisi tersebut. Pada fase ini siswa diberikan perlakuan menggunakan metode TEACCH secara berulang-ulang hingga didapatkan data yang stabil. Intervensi dilakukan sebanyak empat sesi. Intervensi diberikan dengan melatih kemampuan siswa memakai baju menggunakan metode TEACCH. Baseline-2 (A2) adalah kondisi pengulangan dari fase baseline-1 tanpa pemberian intervensi, yang ditujukan sebagai kontrol untuk fase intervensi, sehingga dapat menarik kesimpulan adanya hubungan fungsional antara variabel bebas dan variabel terikat. Pada fase ini pengukuran kemampuan dilakukan sebanyak tiga sesi. Instrument tes yang digunakan sama dengan instrument dalam tahap baseline-1.

Analisis data dibagi dalam analisis dalam kondisi dan analisis antar kondisi. Langkah-langkah dalam menganalisis dalamkondisi, terdiri dari:(1)Menentukan Panjangnya Kondisi, (2) Menentukan Estimasi Kecenderungan Arah, (3) Menentukan Kecenderungan Kestabilan (trend stability), (4) Menentukan Jejak Data, (5) Menentukan Level Stabilitas dan Rentang, (6) Menentukan Level Perubahan. Sedangkan langkahlangkah dalam menganalisis antar kondisi, terdiri dari: (1) Menentukan banyak variabel yang berubah, (2) Menentukan perubahan arah dan efeknya, (3) Menenukan perubahan kecenderungan stabilitas, (4) Menentukan perubahan level, (5) Mencatat apakah presentase overlap.

\section{HASIL DAN PEMBAHASAN}

\section{Hasil}

Subyek dalam penelitian merupakan seorang siswa down syndrome kelas terapi dasar di SLB Idayu II Pakis. Siswa bernama KV. Berusia 5 tahun. Berjenis kelamin laki-laki. Siswa mengalami keterlambatan dalam perkembangan bahasa. Memiliki interaksi berupa kontak mata yang baik. Pada perilaku tidak tampak sebagai anak yang membahayakn diri sendiri. Siswa cenderung tidak hiperaktif. Siswa memiliki kemampuan motorik kasar antara lain: berjalan, berlari, dan duduk dengan baik. Namun memiliki kemampuan yang rendah pada motorik halusnya yaitu mengancingkan baju. Siswa memiliki daya konsentrasi yang mudah terganggu oleh rangsangan di lingkungan sekitarnya.

Langkah pertama dalam pengambilan data yaitu mengukur kemampuan awal subjek dalam kemampuan memakai baju sebelum diberikan intervensi. Kemampuan sosial yang dimaksud adalah kemampuan dalam berinteraksi dengan teman sebaya maupun 
dengan guru/terapis dalam kegiatan bermain.

Pengukuran kondisi baseline 1 (A) dilakukan perhari mulai tanggal 1 sampai dengan 11 Maret 2019. Pengukuran dilakukan sebanyak enam sesi dengan rentang waktu 15-20 menit/hari. Pada kondisi baseline 1 (A) dilakukan pengamatan tanpa perlakuan untuk mengetahui kemampuan awal subjek. Pelaksanaan pengumpulan data dilakukan berdasarkan panduan lembar pengamatan yang dipersiapkan peneliti. Lembar pengamatan terdiri dari empat aspek yang menggambarkan kemampuan memakai baju siswa terhadap guru/terapis maupun dengan teman sebayanya, setiap aspek terdiri dari 2-4 pernyataan.

Tahapan selanjutnya adalah pemberian intervensi kepada subjek penelitian sebanyak enam sesi. Pengambilan data dimulai tanggal 12 sampai dengan 19 Maret 2019 dengan rentang waktu 15-20 menit/ hari dibantu dengan 1 observer yaitu guru kelas. Pengukuran ini dilakukan setelah subjek mendapat perlakuan melalui media papan bergambar tentang langkah-langkah memakai baju. Tahapan akhir adalah melakukan pengukuran baseline-2 (A2). Tahapan baseline-2 (A2) merupakan pengukuran kemampuan akhir subjek dalam kemampuan memakai setelah diberikan perlakuan. Pengukuran kondisi baseline-2 (A2) dilakukan dengan pengamatan tanpa diberikan perlakuan. Pengukuran kondisi baseline-2 (A2) dilakukan sebanyak 3 sesi dengan rentang waktu 15-20 menit/hari. Pengukuran ini dilakukan setelah subjek tidak mendapat perlakuan melalui media papan bergambar. Nilai hasil pengukuran kemampuan memakai baju siswa down syndrome telah diakumulasikan dalam bentuk persen dengan penjelasan sebagai berikut: 1) Pada tes kondisi baseline-1 (A1) dilaksanakan enam sesi. Sesi pertama dengan hasil skor 47, sesi kedua dengan hasil skor 56, sesi ketiga dengan hasil skor 58, sesi keempat hingga keenam dengan hasil skor 61. 2) Pada tes kondisi intervensi (B) dilaksanakan enam sesi. Sesi pertama dengan hasil skor 81, sesi kedua dengan hasil skor 72, sesi ketiga dengan hasil skor 86 , sesi keempat dengan hasil skor 92, sesi kelima dan keenam dengan hasil skor 89. 3) Pada tes kondisi baseline-2 (A2) dilaksanakan tiga sesi. Sesi pertama dengan hasil skor 78, sesi kedua dengan hasil skor 81 , sesi ketiga dengan hasil skor 86 .

Hasil pengukuran kemampuan memakai baju siswa down syndrome di SLB Idayu II Pakis menunjukkan garis yang menggambarkan data keseluruhan. Garis hijau sebagai hasil data pada kondisi baseline-1 (A1). Pada sesi pertama, bantuan fisik dan verbal banyak diterapkan pada aspek kemampuan mengancingkan kemeja. Pada sesi kedua, siswa menunjukkan peningkatan adanya pemahaman istilah kerah kemeja. Siswa mampu mengidentifikasi kerah kemeja tanpa bantuan. Pada sesi ketiga, siswa menunjukkan kemampuan pada indikator memegang kancing baju dengan tangan kanan dengan bantuan verbal saja. Persentase nilai dari sesi pertama hingga sesi ketiga menunjukkan peningkatan. Pada sesi kedua dan ketiga skor siswa tergolong pada kategori rendah. Pada sesi keempat hingga keenam, skor siswa tergolong pada kategori cukup, meski begitu termasuk mengalami peningkatan dari sesi sebelumnya. Hal tersebut dapat dikatakan bahwa pada pengukuran kondisi baseline-1 (A1) telah mengalami kestabilan.

Garis biru sebagai hasil data pada kondisi intervensi (B), Pada sesi pertama, siswa tidak memerlukan bantuan fisik. Pada sesi kedua, bantuan fisik diperlukan pada aspek kemampuan mengancingkan baju, maka hasil skor siswa pun menurun. Pada sesi ketiga, siswa mampu menunjukkan kemampuannya lebih banyak tanpa bantuan, Pada sesi keempat, siswa menunjukkan kemampuannya lebih banyak tanpa bantuan. Persentase nilai dari sesi pertama hingga sesi kedua menunjukkan penurunan, namun pada sesi ketiga hingga keempat menunjukkan kenaikan dari hasil skor dari sesi sebelumnya. Pada sesi keempat dan kelima, meski skor siswa mengalami penurunan, namun tergolong pada kategori sangat baik. Hal tersebut dapat dikatakan bahwa pada pengukuran pada kondisi intervensi (B) telah mengalami kestabilandan. Garis coklat sebagai hasil data pada kondisi baseline-2 (A2). Persentase nilai dari sesi pertama hingga sesi ketiga menunjukkan tingkat kestabilan berdasarkan kategori nilai yang tergolong baik. Hal tersebut dapat dikatakan bahwa pengukuran pada kondisi baseline-2 (A2) telah mengalami kestabilan.

\section{Pembahasan}

Penerapan langkah-langkah metode TEACCH sesuai prinsip dasarnya untuk pelaksanaan tes kemampuan memakai baju. Reward diberikan pada siswa ketika dengan mudah bersedia melaksanakan latihan kemampuan memakai baju bahkan juga saat pelaksanaan tes kemampuannya, siswa dengan tenang mengikuti semua instruksi peneliti. Reward yang diberikan sesuai dengan benda yang disukai dan diminati siswa yaitu buku cerita bergambar, bola sepak, dan pemberian jam pulang yang sesuai waktunya. Pada pelaksanaan kegiatan memakai baju, siswa didukung dengan bantuan media papan bergambar sebagai pedoman bagi siswa untuk mengikuti instruksi pelatih sesuai langkah-langkahnya. Bantuan yang diperoleh siswa dapat secara fisik maupun verbal pada tiap sesi praktiknya.

Penerapan metode TEACCH memerlukan guru, terapis maupun orang tua yang perlu memahami cara anak dalam memahami dan bertindak, kemampuan dan hambatan terkait dengan gejalanya, karena peran mereka adalah untuk melayani dalam pengenalan aspek kehidupan termasuk berbagai prosedur lingkungan sekitar pada siswa down syndrome. Indikator pelaksanaan dalam penelitian ini mengacu pada empat prinsip dasar metode TEACCH. 
Tabel 2 Data Analisis Dalam Kondisi

\begin{tabular}{llll}
\hline Kondisi & Baseline & Intervens & Baseline \\
\hline P Kondisi & 6 & 6 & 3 \\
Kecenderungan & & & \\
Arah & & & \\
& $(+)$ & $(+)$ & $(+)$ \\
Kecenderungan & Stabil & Stabil & Stabil \\
S & $(83,4 \%)$ & $(83,4 \%)$ & $(100 \%)$ \\
Jejak Data & Stabil & Stabil & Stabil \\
& $(47 \%$ & $(72 \%$ & - \\
& $61 \%)$ & $92 \%)$ & $86 \%)$ \\
Level Stabilitas & & & - \\
Rentang & & & $(+)$ \\
& $(+)$ & $(+)$ & $(78 \%$ \\
Perubahan Level & $47 \%$ & $-81 \%$ & - \\
& $61 \%$ & $89 \%$ & $86 \%$ \\
& & $(+8)$ & $(+8)$ \\
& $(+14)$ & & \\
\hline
\end{tabular}

Tabel 3 Data Analisis Dalam Kondisi

\begin{tabular}{llll}
\hline Kondisi & Baseline & Intervens & Baseline \\
\hline $\begin{array}{l}\text { P Kondisi } \\
\text { Kecenderungan }\end{array}$ & 6 & 6 & 3 \\
Arah & & & \\
& $(+)$ & $(+)$ & $(+)$ \\
Kecenderungan & Stabil & Stabil & Stabil \\
S & $(83,4 \%)$ & $(83,4 \%)$ & $(100 \%)$ \\
Jejak Data & Stabil & Stabil & Stabil \\
& $(47 \%$ & $-(72 \%$ & - \\
& $61 \%)$ & $92 \%)$ & $86 \%)$ \\
Level Stabilitas & & & \\
Rentang & & & $(+8 \%)$ \\
& $(+)$ & $(+)$ & $(+)$ \\
P e r u b a h a n & $47 \%$ & $81 \%$ & $-78 \%$ \\
Level & $61 \%$ & $89 \%$ & $86 \%$ \\
& & $(+8)$ & $(+8)$ \\
& $(+14)$ & & \\
\hline
\end{tabular}

Menurut metode TEACCH, keterampilan yang paling fungsional untuk anak berkebutuhan khusus adalah pekerjaan rutin yang melibatkan pemeriksaan terhadap jadwal anak dan mengikuti sistem kerja yang ditetapkan. Struktur fisik diwujudkan dengan penyediaan karet khusus sebagai tempat berpijak siswa dalam melakukan kegiatan memakai baju. Penyusunan jadwal kegiatan dengan menerapkan penggunaan urutan gambar yang menjelaskan tiap kegiatan disusun dari atas ke bawah. Sistem kerja diwujudkan saat mengorganisasikan dalam penggunaan dan peletakan kembali peralatan yang digunakan dalam memakai baju berdasarkan urutan tertentu misalnya dari bawah ke atas.
Pengunaan media dukungan visual untuk membuat urutan kegiatan latihan yang dapat diprediksi sehingga tugas individu dapat dimengerti siswa down syndrome. Informasi visual ditunjukkan dalam penggunaan setting tempat yang dibatasi atau dipisahkan secara visual, jadwal yang divisualkan, dan sistem kerja yang diapat dipahami secara visual.

Siswa down syndrome sering memiliki tingkat focus yang intens dan bersemangat pada hal-hal yang menarik. Minat khusus sangat penting bagi siswa berkebutuhan khusus, mirip dengan hobi yang intens. Minat khusus diwujudkan dalam bentuk penguat yang diterapkan pada penelitian ini yaitu berupa mainan bola-bola kecil karena siswa tertarik pada mainan tersebut. Penguat diberikan setelah siswa memperoleh keberhasilan menyelesaikan kegiatan berpakaian. Komunikasi bermakna dilakukan dengan menunjukkan gambar peralatan dan cara memakai baju disertai perintah yang diucapkan peneliti sesuai dengan gambar yang ditunjukkan. Misalnya siswa ditunjukkan gambar baju bersamaan dengan peneliti mengatakan ambil baju, yang demikian diharapkan siswa akan paham dan mengambil baju. Pujian verbal dapat memotivasi sebagian besar anak berkebutuhan khusus saat dalam masa perkembangan. Penelitian ini menggunakan metode TEACCH yang dilaksanakan sesuai desain penelitian A-B-A' dengan banyaknya sesi berjumlah lima belas sesi. Sesi baseline-1 (A1) dilaksanakan enam sesi dengan hasil skor yang menunjukkan rendahnya kemampuan siswa dalam memakai baju secara mandiri. Sesi intervensi (B) dilaksanakan enam sesi hingga skor siswa terlihat stabil dan menunjukkan peningkatan skor dengan adanya bantuan berupa papan bergambar pada penerapan metode. Sesi baseline-2 (A2) dilaksanakan tiga sesi, meski mengalami penurunan skor dari hasil sesi sebelumnya, namun pada sesi ini skor siswa tergolong baik.

Penjelasan analisis visual dalam kondisi pada penelitian ini sebagai berikut: 1) Panjang kondisi pada kondisi baseline-1 (A1) yaitu sebanyak enam sesi, pada kondisi intervensi (B) yaitu sebanyak enam sesi, dan pada kondisi baseline-2 (A2) yaitu sebanyak tiga sesi. 2) Estimasi kecenderungan arah data pada masing-masing kondisi baseline-1 (A1), intervensi (B), dan baseline-2 (A2) yaitu meningkat. Garis meningkat tersebut diartikan bahwa intervensi berupa metode TEACCH dapat membantu dalam meningkatkan kemampuan memakai baju siswa down syndrome dan menunjukkan adanya pengaruh dari penerapan intervensi tersebut. 3) Kecenderungan stabilitas data pada kondisi baseline-1 (A1) dan intervensi (B) memperoleh hasil yang sama yaitu sebesar 83,4\%. Pada kondisi baseline-2 (A2) memperoleh hasil 100\%. Dari ketiga hasil perolehan siswa menunjukkan bahwa data tergolong stabil. 4) Kecenderungan jejak data pada masing-masing kondisi baseline-1 (A1), intervensi (B), dan baseline-2 (A2) tergolong meningkat. 
Tabel 4 Data Analisis Antar Kondisi

\begin{tabular}{|c|c|c|}
\hline $\begin{array}{l}\text { Perbandingan } \\
\text { Kondisi }\end{array}$ & $\mathrm{A} 1 / \mathrm{B}$ & $\mathrm{B} / \mathrm{A} 2$ \\
\hline $\begin{array}{l}\text { Jumlah Variabel } \\
\text { diubah }\end{array}$ & 1 & 1 \\
\hline \multirow[t]{2}{*}{$\begin{array}{l}\mathrm{P} \text { e } \mathrm{r} \text { u b a } \mathrm{h} \text { a } \\
\text { Kecenderungan } \\
\text { Arah dan Efeknya }\end{array}$} & & \\
\hline & $(+)$ & $(+)$ \\
\hline $\begin{array}{l}\text { P e r u b a h a } n \\
\text { Stabilitas }\end{array}$ & Stabil ke stabil & Stabil ke stabil \\
\hline Perubahan Level & $\begin{array}{l}61 \%-81 \% \\
(+20)\end{array}$ & $\begin{array}{l}89 \%-86 \% \\
(-3)\end{array}$ \\
\hline $\begin{array}{l}\text { P r e s e } \mathrm{nt} \text { a s e } \\
\text { Overlap }\end{array}$ & $0 \%$ & \\
\hline
\end{tabular}

Peningkatan tersebut menunjukkan bahwa intervensiberupa metode TEACCHdapatmeningkatkan kemampuan memakai baju siswa down syndrome. 5) Level stabilitas pada masing-masing kondisi meningkat secara stabil dengan rentang pada kondisi baseline-1 (A1) sebesar 47\% - 61\%, pada kondisi baseline-2 (A2) sebesar 72\% - 92\%, dan pada kondisi baseline-2 (A2) sebesar $78 \%$ - 86\%. 6) Perubahan level pada masingmasing kondisi mengalami peningkatan dengan hasil peningkatan pada kondisi baseline-1 (A1) dengan peningkatan skor sebesar 14, kondisi intervensi (B) dengan peningkatan skor sebesar 8 , dan pada kondisi baseline-2 (A2) dengan skor sebesar 8 .

Penjelasan analisis visual antar kondisi pada penelitian ini sebagai berikut: 1) Jumlah variabel yang diubah pada kondisi baseline-1 (A1) ke intervensi (B) dan dari kondisi intervensi (B) ke baseline-2 (A2) adalah satu variabel yaitu kemampuan memakai baju. 2) Perubahan arah dan efek pada masing-masing kondisi mengalami kenaikan sehingga menunjukkan efek yang positif $(+)$. Dapat dijelaskan bahwa tingkat pencapaian kemampuan memakai baju siswa mengalami peningkatan setelah diberikan intervensi penerapan metode TEACCH. 3) Perubahan stabilitas dari kondisi baseline-1 (A1) ke kondisi intervensi (B) yaitu stabil ke stabil dengan efek yang positif $(+)$. Pada kondisi intervensi (B) ke kondisi baseline-2 (A2) yaitu stabil ke stabil dengan efek yang juga positif $(+)$. 4) Perubahan level antar kondisi baseline-1 (A1) dengan kondisi intervensi (B) diperoleh adanya peningkatan kemampuan dari $61 \%$ menuju $81 \%$ dengan selisih +20 . Pada kondisi intervensi (B) dengan kondisi baseline-2 (A2) diperoleh adanya penurunan kemampuan dari 89\% menjadi 86\% dengan selisih -3 . 5) Data tumpang tindih pada kondisi baseline-1 (A1) ke kondisi intervensi (B) yaitu $0 \%$, menunjukkan tidak ada data pada kondisi intervensi (B) yang masuk dalam rentang kondisi baseline-1 (A1).

Analisis dalam kondisi dan antar kondisi berdasarkan perhitungan diketahui bahwa skor presentase yang diperoleh siswa dalam tes kemampuan memakai baju lebih banyak menunjukkan peningkatan dan kestabilan nilai. Pada presentase data overlap menunjukkan $0 \%$, yang diartikan bahwa metode TEACCH mampu memberi pengaruh yang baik terhadap kemampuan memakai baju siswa. Semakin kecil persentase hasil data overlap, maka menunjukkan terdapat pengaruh metode TEACCH terhadap target behavior yaitu kemampuan bina diri memakai baju siswa down syndrome.

Penelitian mengenai pengaruh metode TEACCH terhadap kemampuan bina diri memakai baju siswa down syndrome yang menunjukkan pengaruh dari kondisi baseline-1 (A1) menggunakan media papan bergambar kondisi intervensi (B) dan diuji kembali dalam kondisi baseline-2 (A2). Hal ini terbukti berdasarkan hasil persentase overlap data sebesar $0 \%$ menunjukkan bahwa pemberian intervensi menggunakan metode TEACCH berpengaruh terhadap target behaviour yaitu kemampuan bina diri memakai baju pada siswa down syndrome di SLB Idayu II Pakis, Malang.

\section{KESIMPULAN DAN SARAN}

\section{Kesimpulan}

Berdasarkan hasil analisis dan pembahasan yang telah diuraikan dapat disimpulkan bahwa penggunaan metode TEACCH dapat memberi pengaruh terhadap kemampuan bina diri memakai baju siswa down syndrome subjek KV. TEACCH sebagai salah satu program yang merefleksikan dan berkontribusi pada pelaksanaan intervensi dasar bagi anak berkebutuhan khusus. Hal tersebut dapat dibuktikan dengan hasil overlap data sebesar $0 \%$, yang menunjukkan bahwa semakin kecil persentase overlap data, maka semakin baik pengaruh intervensi terhadap target behaviour.

\section{Saran}

Siswa down syndrome tentunya belajar dan mengambil keterampilan baru sepanjang hidup mereka, tetapi mungkin membutuhkan waktu lebih lama untuk mencapai beberapa tujuan penting. pengembangan pembelajaran keterampilan bina diri yang mendukung kemudahan siswa diperlukan agar siswa dapat beraktivitas secara mandiri. Diharapkan agar setiap pembelajaran memungkinkan siswa untuk mengembangkan kompetensinya melalui penerapan metode TEACCH dengan peran aktif dari guru, orang tua, maupun ahli terapi metode TEACCH. 


\section{DAFTAR PUSTAKA}

Bolagh, R., Zahednezhad, H., \& Vosoughillkhchi, S. (2013). The Effectiveness of Treatment Education Methods in Children with Autism Disorders. $3^{\text {rd }}$ World Conference on Psychology, Counselling and Guidance, http://www.sciencedirect.com/

DSAWM. (2010). Supporting the Student with Down Syndrome in Your Classroom. DSAWM Educator Manual, http://www.kcdsg.org/

GHR. (2019). Your Guide to Understanding Genetics Conditions, https://ghr.nlm.nih.gov/condition/ down-syndrome

Gunarhadi. (2005). Penanganan Anak Sindroma Down dalam Lingkungan Keluarga dan Sekolah. Jakarta: Dirjen Dikti Depdiknas.

Handojo, Y. (2009). Autisme Pada Anak. Jakarta: PT Bhuana Ilmu Populer.

Meinapuri, M. (2013). Polimorfisme Gen Apolipoprotein E pada Penderita Sindrom Down Trisomi 21. Jurnal Kesehatan Andalas, Vol. 2, No. 1, http://jurnal.fk.unand.ac.id/

Mesibov, G., \& Shea, V. (2009). The TEACCH Program in the Era of Evidence-based Practice. Journal of Autism and Developmental Disorders, http://interactingwithautism.com/
Shenai, N. G. (2014). Development of Self Care Skills Scale for Children with Developmental Disorders: A Pilot Study. The Indian Journal of Occupational Therapy, Vol. 46, No. 1, http://medind.nic.in/

Spivey, B., L. (2006). What Is Down Syndrome? Super Duper Publications, No. 116, http://www. superduperinc.com/

Sunanto, J. (2005). Penelitian Dengan Subjek Tunggal. Bandung: UPI Press.

Tuteja, S., \& Nigam, V. (2017). Assistive Clothing Designs for Mentally Retarded. Internasional Journal of Reasearch- Granthaalayah, http://www. researchgate.net/

Universitas Negeri Malang. (2017). Pedoman Penulisan Karya Ilmiah. Malang: UM Press.

Wantah, M., J. (2007). Pengembangan Kemandirian Anak Tunagrahita Mampu Latih. Jakarta: Depdiknas.

Widati, S. (2013). Pengajaran Bina Diri dan Bina Gerak (BDBG). Modul. Bandung: Universitas Pendidikan Indonesia. 